\title{
ФИЛОЛОГИЧЕСКИЕ НАУКИ.
} ЛИТЕРАТУРОВЕДЕНИЕ

\section{ЖЕНЩИНА КАК ДРУГОЙ В СОВЕТСКОМ ДИСКУРСЕ 1970-80-Х ГГ.}

\author{
(C) Антон Афанасьев
}

\section{WOMAN AS THE OTHER IN THE SOVIET DISCOURSE OF THE 1970- 1980s}

\begin{abstract}
Anton Afanasev
This article is devoted to the understanding of woman as the Other in the underground and official Soviet discourse of the 1970-1980s. The author discusses the phenomenon of the Leningrad dissident feminism, which is underresearched in the Russian humanitarian thought. It was the situation of awareness of one's otherness that was the impetus for making it an independent branch of the underground. Our study is based on the almanac "Woman and Russia" (1980) and the journal "Maria" (1981).

As a result of the study we have come to the conclusion that first of all, it is necessary to talk about the position of women as the inner Other when speaking about the Leningrad dissident feminism: the united female part of the Leningrad underground turned out to be its misunderstood male part. The original principle of equality, which meant both joint creative work and common danger, was replaced by the awareness of selves as Foes among Friends; the image of man was reduced by the accusation of cowardice, and the image of woman was created, the woman who was not afraid of danger in the face of the truth. Thus, the established gender stereotypes about a brave man and a fearful woman were shattered, and women's identity was reconstructed.

In addition, according to the new mythology, the woman was given the role of the Savior of Russia. Salvation was not only the creation of the "mother family" (N. Malakhovskaya), that is, the changing of the social and existential status of women, but also the creation of a different culture.
\end{abstract}

Keywords: image of the Other, woman as the Other, Soviet discourse of the 1980s, Leningrad feminism, almanac "Woman and Russia", journal "Maria".

Данная статья посвящена осмыслению женщины как Другого в официальном и андеграундном советском дискурсе 1970-80-х гг. Автором рассматривается феномен ленинградского диссидентского феминизма - явления, которое в отечественной гуманитарной мысли практически не изучено. Именно ситуация осознания своей Другости была толчком для выделения его в самостоятельную ветвь андеграунда. В качестве источника и одновременно материала исследования выступили альманах «Женщина и Россия» (1980) и журнал «Мария» (1981).

В результате исследования автор приходит к выводу, что относительно ленинградского диссидентского феминизма в первую очередь нужно говорить о положении женщины как внутреннего Другого: объединившаяся женская часть ленинградского андеграунда оказалась непонятой мужской частью. Изначальная установка на равноправие, которое заключалось как в совместном творчестве, так и в общей опасности, сменяется осознанием себя как Другого среди Своих; происходит снижение образа мужчин обвинением в трусости и создается образ не боящейся опасности перед лицом правды женщины. Таким образом, начинает одновременно происходить расшатывание устоявшихся гендерных стереотипов о смелом мужчине и боязливой женщине и реконструкция женской идентичности.

Кроме того, в выстраиваемой новой мифологии женщине отводится роль спасительницы России. Спасение заключается не только в создании «материнской семьи» (Н. Малаховская), то есть изменении социального и экзистенциального статуса женщины, но и в создании иной культуры.

Ключевые слова: образ Другого, женщина как Другой, советский дискурс 1980-х годов, ленинградский феминизм, альманах «Женщина и Россия», журнал «Мария». 
Как справедливо отмечает в своей монографии «Образ Другого в текстах культуры» (2012) Е. Н. Шапинская, «в течение долгого времени женщина оставалась одним из самых значимых Других культуры. Роль Другого приписывалась ей андроцентрической культурой, где власть концентрировалась в руках маскулинного субъекта» [Шапинская]. Действительно, если мы обратимся к древним цивилизациям (минойской, микенской), то обнаружим там культ Великой Богини и существовавший паритет между мужчинами и женщинами в устроительстве жизни. Впоследствии гармония между двумя началами исчезает, и женщины в реальной жизни (как и богини в мифологиях) получают вторичный статус. Более того, женщины становятся Другими по отношению к мужчинам.

Одной из первых женскую Другость философски осмыслила С. де Бовуар в своей знаменитой книге «Второй пол» (1949, впервые на русском языке вышла в 1997 году):

Человечество создано мужским полом, и это позволяет мужчине определять женщину не как таковую, а по отношению к самому себе; она не рассматривается как автономное существо <...> Она - лишь то, что назначит ей мужчина. Таким образом, ее называют «полом», подразумевая под этим, что мужчине она представляется прежде всего существом определенного пола: для него она является полом, а значит, является им абсолютно. Она самоопределяется и выделяется относительно мужчины, но не мужчина относительно нее; она - несущественное рядом с существенным. Он - Субъект, он - Абсолют, она - Другой [Бовуар, с. 28].

Быть изначально и постоянно Другой - удел женщины, по Бовуар.

Советским женщинам идеи С. де Бовуар, как и других представительниц феминистского движения в многочисленных его проявлениях, были незнакомы даже в конце 1980-х годов. Писательница Светлана Василенко вспоминает:

Но как и раньше, в глухое осеннее время застоя, так и теперь, в весеннее время перемен (в 1988 году. $A$. $A$.), никто и слыхом не слыхал о таком понятии, как феминизм. Как я сейчас понимаю, идеи феминизма держали от нас за семью запорами, боясь их больше, чем идей антикоммунизма, так как они потрясали не только социальные основы, а основы основ мироустройства нашей патриархальной страны. Феминизм был понятием ругательным, им обозначались какие-то уродливые, противоестественные явления западной жизни, о которых можно говорить только шепотом. Слово «феминистка» звучало как оскорбление [Василенко].
Однако внутри советского дискурса в андеграундной среде параллельным западному курсом развивается уникальное явление - ленинградский диссидентский феминизм, для которого ситуация осознания своей Другости была толчком для выделения его в самостоятельную ветвь андеграунда.

Несмотря на то что для своего времени ленинградский феминизм был явлением резонансным, данный феномен не получил научного осмысления в отечественной гуманитарной мысли. Нам удалось найти лишь две научные статьи, в которых есть попытки анализа этого явления [Киналь, Королева], [Митрофанова]. Поэтому скажем несколько слов об истории возникновения и составе ленинградского диссидентского феминизма.

Основными его участницами стали Татьяна Горичева, Татьяна Мамонова, Наталия Малаховская, Юлия Вознесенская. Своеобразным летописцем этого движения оказалась Наталия Малаховская, которая подробно рассказала о возникновении феминизма 1970-х гг.:

В Ленинграде в середине 70-х годов существовали так называемые нонконформистские издания, например, журнал «37» и альманах «Часы». В них работали как мужчины, так и женщины, зачастую в довольно опасных условиях, однако этим изданиям в течение нескольких лет удавалось сохраняться. С течением времени женская часть редакции журнала «37» (Татьяна Горичева была соредактором этого издания. - A. А.) начала чувствовать себя как бы нонконформистами в среде нонконформистов: материалы, которые стремились опубликовать женщины, мужчинам казались слишком острыми, слишком социально направленными, - одним словом, слишком опасными [Малаховская].

Приведенная цитата ярко иллюстрирует отличие западного феминизма от ленинградского. В западном феминизме эссенциалистский (сформировавшийся в патриархатном обществе и культуре) тезис о Другости женщины есть посыл к мысли и движению за равноправие. В ленинградском феминизме перформативный («Женщиной не рождаются, женщинами становятся, что невероятно трудно в нашем обществе» [Мария, с. 10]), сконструированный официальной советской идеологией, но оказавшийся в действительности ложным тезис о равноправии женщин ведет к протесту против среднего пола (гермафродитства) homo soveticus, обнаружению в себе пола / отличия и деконструкции гендерных стереотипов (творчеству новой мифологии), «признанию права на различие вообще, и на „женское различие“, в частности, становится 
важным условием изменения советского жизненного строя» [Женский проект, с. 12-13]).

Еще раз обратимся к композиции высказывания Н. Малаховской: изначальная установка на равноправие, которое заключалось как в совместном творчестве (работа над журналом), так и в общей опасности («В них работали как мужчины, так и женщины, зачастую в довольно опасных условиях»), сменяется осознанием себя как Другого среди Своих (Свои в данном случае круг ленинградских диссидентов) - «женская часть <..> начала чувствовать себя как бы нонконформистами в среде нонконформистов»). Последнее же предложение отрывка («материалы, которые стремились опубликовать женщины, мужчинам казались слишком острыми, слишком социально направленными, - одним словом, слишком опасными») подводит окончательную черту разрыва с бывшими Своими, снижая образ мужчин обвинением в трусости и создавая образ не боящейся опасности перед лицом правды женщины. Таким образом, начинает одновременно происходить расшатывание устоявшихся гендерных стереотипов о смелом мужчине и боязливой женщине и реконструкция женской идентичности.

В сентябре 1979 года в ленинградском самиздате в количестве 10 экземпляров (впоследствии практически все они будут конфискованы КГБ) выходит альманах «Женщина и Россия». Структурно он состоял из двух блоков. Первый блок составляли публицистические материалы, во втором блоке были собраны художественные произведения (небольшие рассказы, лирические этюды, стихотворения), также поднимающие социальные проблемы существования женщины в советском государстве.

Подобную структуру имел и пришедший на смену альманаху журнал «Мария», работа над которым началась в декабре 1979 года. В январе 1980 года «макет первого номера этого журнала был изъят при обыске» [Малаховская], однако его все же удалось издать в тамиздате в 1981 году. Поскольку идеологами альманаха «Женщина и Россия» и журнала «Мария» являлись одни и те же люди, проблематика была одинаковой, то вслед за С. Ярошенко [Женский проект, с. 11] считаем возможным рассматривать оба этих издания как единый независимый женский журнал.

Начнем с проблематики журнала. Как вспоминает Н. Малаховская, писали «о проблемах социальных, о том, что творится в родильных домах, в абортариях, в семьях, превращенных для многих женщин и детей в маленькие домашние концлагеря, о детских садах, лагерях и школах» [Малаховская]. Иными словами, о всем том, что входит в сферу понятия «женский опыт». Это понятие занимает центральное место в феминистской критике, поскольку оно, во-первых, способствует формированию Другости, женского «различия» в диссидентской среде, во-вторых, является важным инструментом «сопротивления системе» [Женский проект, с. 7].

Фиксация «женского опыта» происходила с помощью использовавшейся стратегии «голоса»,

$<\ldots>$ которая рассматривается и проявляется с двух сторон. С одной стороны, через обсуждение чувствительности к неравенству, осознания несправедливости и артикуляции проблем, т. е. понимание механизмов действия власти. А с другой - через обозначение позиции и собственного интереса, предложение узнаваемого образа и стратегии его продвижения, т. е. включение в область политики и перераспределения власти [Там же, с. 8].

Стратегия «голоса» своим источником, безусловно, имеет стратегию «женского письма» В своем знаменитом эссе «Хохот медузы» Э. Сиксу обращается к женщинам с вопросом:

И почему же вы не пишете? Пишите! Письмо как процесс - это только для вас [Сиксу, с. 801].

Этот же призыв мы можем обнаружить и в стихотворении Татьяны Мамоновой «Ты рождена и жизни суету...», вошедшее в альманах «Женщина и Россия»:

пиши свои стихи

пиши пиши

и будь не слишком

к ближнему сурова [Женщина и Россия, с. 100].

С одной стороны, стратегия «голоса» отличается от стратегии «женского письма», поскольку, как уже отмечалось в приведенной выше цитате, стратегия «голоса» была политически ангажирована и использовалась в первую очередь при озвучивании социальных проблем. Однако сам факт включения в независимый женский журнал поэтических и прозаических текстов говорит о желании произнести слово художественное. Это связано с особым местом концепции творчества в мировоззренческой системе ленинградских феминисток.

Изначальный тезис выстраиваемой концепции - в советском государстве женщине в праве творить отказано:

Моцартов среди женщин еще не было - и быть не может - не так созданы Господом Богом [Там же, с. 37]. 
Однако в выстраиваемой новой мифологии женщине отводится роль Мессии - Спасителя России:

В России нынче должна родиться новая женщина - свободная и независимая, однако не употребляющая свою свободу во вред ближнему, а преобразующая ее в творческий порыв, женщина, поднявшаяся до понимания своей высокой задачи, осознавшая боль века как свою собственную боль, умеющая сделать чужое страдание своей судьбой [Мария, с. 8].

Спасение заключается не только в создании материнской семьи, то есть изменении социального и экзистенциального статуса женщины, но и в создании иной культуры:

Слово рвется из твой души, оно разрывает тебя, смертный грех - убить его в себе, не дать ему жизнь. Для того, чтобы стать творцом, женщина должна проявить усилия, мужчинам неизвестные, усилия героические. Но она пойдет на это - чтобы создать новую культуру, которая изменит жизнь [Женщина и Россия, c. 37].

Одно из ключевых мест в новой культуре предоставлялось Божьей Матери как образу идеального Человека, идеальной женщины. Это очень было важно, в частности, для Т. Горичевой, поскольку, как она пишет, «все советское воспитание ориентировано на абстрактноодносторонний ,псевдомужской“" идеал» [Там же, с. 22]. По выстраиваемому автобиографическому мифу, в «дохристианский» период в ней господствовало иррациональное женское бессознательное: «женское - это иррациональная, демоническая стихия, она страшит своей хаотичностью и непросветленностью» [Там же, с. 25]. Обращение к Божьей Матери позволило автору «открыть и возродить в себе женское начало во всей его чистоте и абсолютности» [Там же].

В мае 1980 года во время «антидиссидентского предолимпийского марафона» действия КГБ в отношении участниц ленинградского феминизма активизировались. В связи с этим 11 мая эмигрировала Юлия Вознесенская, а 9 июля Татьяне Мамоновой, Татьяне Горичевой и Наталии Малаховской был поставлен ультиматум эмиграция или тюрьма. 10 июля все трое покидают СССР. Журнал «Мария» некоторое время продолжил свое существование, но и он окончательно закрылся в 1982 году.

На этом короткая история ленинградского феминизма закончилась. Но, как мы уже отмечали выше, недооценивать его значение нельзя, поскольку именно он стал источником расцвета новой российской женской прозы.
Таким образом, представительницы ленинградского диссидентского феминизма в своих декларациях и поведенческих стратегиях создали две модели женщины как Другой. Первую модель можно назвать «внутренней» Другостью: внутренней по отношению к той андеграундной среде, из которой они вышли, когда оказались Другими среди Своих. Однако нельзя в отношении ленинградского диссидентского феминизма не сказать и о Другости «внешней», понимаемой не столько в общекультурном плане, сколько в контексте советского дискурса: невозможность открыто говорить правду о положении женщин превратила их во врагов системы.

\section{Список литературы}

Бовуар С. де. Второй пол. М. Прогресс; СПб.: Алетейя, 1997. 832 с.

Василенко С. «Новые амазонки» (Об истории первой литературной женской писательской группы. Постсоветское время). URL: http://www.a-z.ru/ women_cd1 $/ \mathrm{html} / \mathrm{vasilenko \_ e.htm} \mathrm{(дата} \mathrm{обращения:}$ 19.03.2019).

Женский проект: метаморфозы диссидентского феминизма во взглядах молодого поколения России и Австрии. СПб.: Алетейя, 2011. 336 с.

Женщина и Россия. Альманах «Женщинам о женщинах». Paris: Editions Des femmes, 1980. 143 c.

Киналь А. В., Королева Л. А. Независимый альманах «Женщины и Россия» в СССР // Электронный научно-практический журнал «Современные научные исследования и инновации». 2015. № 3. Ч. 3. URL: http://web.snauka.ru/issues/2015/03/48685 (дата обращения: 19.03.2019).

Малаховская Н. Как начиналось женское движение в конце 70-х [начало] // ФЕМИНФ. 1992. Вып. 1. URL http://www.owl.ru/win/books/feminf/01/02.htm (дата обращения: 09.02.2019)

Мария. Журнал российского независимого женского религиозного клуба «Мария». Вып. 1. Л.Франкфурт-на-Майне, 1981. 86 с.

Митрофанова А. Ленинградский феминизм 70-х. URL:

http://www.russia.ru/podosokorskiy/status/2f1050000075 7 (дата обращения: 19.03.2019).

Сиксу Э. Хохот Медузы // Введение в гендерные исследования. Ч. 2. СПб.: Алетейя, 2001. С. 799-821.

Шапинская Е. Н. Гендер, конструирующий «Другость»// Шапинская Е. Н. Образ Другого в текстах культуры. М.: КРАСАНД, 2012. URL: https://studref.com/544929/kulturologiya/gender_konstrui ruyuschiy_drugost (дата обращения: 23.04.2019).

\section{References}

Bovuar, S. de (1997). Vtoroi pol [The Second Sex]. 832 p. Moscow. Progress; Saint-Petersburg. Aleteiia. (In Russian) 
Kinal', A. V., Koroleva, L. A. (2015). Nezavisimyi al'manakh "Zhenshchiny $i$ Rossiia" v SSSR [The Independent Almanac "Women and Russia" in the USSR]. Elektronnyi nauchno-prakticheskii zhurnal "Sovremennye nauchnye issledovaniia i innovatsii". No 3, Ch. 3. URL: http://web.snauka.ru/issues/2015/03/48685 (accessed: 19.03.2019). (In Russian)

Malakhovskaia, N. (1992). Kak nachinalos' zhenskoe dvizhenie $v$ kontse 70-kh (nachalo) [How the Women's Movement Began in the Late 1970s (the Beginning)]. FEMINF. Issue. 1. URL http://www.owl.ru/win/books/ feminf/01/02.htm (accessed: 19.03.2019). (In Russian)

Mariia. Zhurnal rossiiskogo nezavisimogo zhenskogo religioznogo kluba "Mariia" (1981) [Maria. Journal of the Russian Independent Women's Religious Club "Maria"]. 86 p. Leningrad. Frankfurt, Issue 1. (In Russian)

Mitrofanova, A. Leningradskii feminizm 70-kh [The Leningrad Feminism of the 1970s]. URL: http://www.russia.ru/podosokorskiy/status/2f1050000075 7 (accessed: 19.03.2019). (In Russian)

Shapinskaia, E. N. (2012). Gender, konstruiruiushchii "Drugost'" [Gender, Constructing "Otherness"]. Shapinskaia E. N. Obraz Drugogo v tekstakh kul'tury.
Moscow. KRASAND. URL: https://studref.com/544929/ kulturologiya/gender_konstruiruyuschiy_drugost (accessed: 23.04.2019). (In Russian)

Siksu, E. (2001). Khokhot Meduzy [The Laughter of Medusa]. Vvedenie v gendernye issledovaniia. SaintPetersburg. Aleteiya. Ch 2, pp. 799-821. (In Russian)

Vasilenko, S. "Novye amazonki" (Ob istorii pervoi literaturnoi zhenskoi pisatel'skoi gruppy. Postsovetskoe vremia) ["New Amazons" (On the history of the first literary women writers' group. Post-Soviet time)]. URL: http://www.a-z.ru/women_cd1/html/vasilenko_e.htm (accessed: 19.03.2019). (In Russian)

Zhenshchina i Rossiia. Al'manakh "Zhenshchinam o zhenshchinakh" (1980) [Woman and Russia. The Almanac "Women about Women"]. 143 p. Paris, Editions Des femmes. (In Russian)

Zhenskii proekt: metamorfozy dissidentskogo feminizma vo vzgliadakh molodogo pokoleniia Rossii $i$ Avstrii (2011) [Women's Project: Metamorphoses of Dissident Feminism in the Views of the Younger Generation of Russia and Austria]. 336 p. Saint-Petersburg, Aleteiia. (In Russian)

\author{
Афанасьев Антон Сергеевич, \\ кандидат филологических наук, \\ доцент, \\ Казанский федеральный университет, \\ 420008, Россия, Казань, \\ Кремлевская, 18. \\ a.s.afanasyev@mail.ru
}

